\title{
Carbon dioxide abatement in China: Revisiting the role of renewable energy, financial development and urbanization from Quantile ARDL approach
}

\section{Arshian Sharif}

Malaysia University of Science and Technology

Hamid hussain ( $\nabla$ hhussain@iba.edu.pk)

Institute of Business Administration Karachi: Institute of Business Administration

https://orcid.org/0000-0002-8519-7556

Hammed Oluwaseyi Musibau

University of Tasmania Tasmanian School of Business and Economics

Avik Sinha

Goa Institute of Management

\section{Research Article}

Keywords: Renewable energy, financial advancement, QARDL, China

Posted Date: April 27th, 2021

DOI: https://doi.org/10.21203/rs.3.rs-237865/v1

License: (9) This work is licensed under a Creative Commons Attribution 4.0 International License.

Read Full License 


\title{
Carbon dioxide abatement in China: Revisiting the role of renewable energy, financial development and urbanization from Quantile ARDL approach
}

\author{
Arshian Sharif \\ Othman Yeop Abdullah Graduate School of Business \\ University Utara Malaysia \\ Sintok, Kedah, Malaysia \\ Email: arshian.aslam@gmail.com \\ Hamid Hussain \\ Department of Economics, \\ Institute of Business Administration \\ Karachi Pakistan. \\ Email: hhussain@iba.edu.pk \\ Hammed Oluwaseyi Musibau \\ Tasmanian School of Business and Economics, \\ University of Tasmania, \\ Sandy Bay Campus, Hobart, Australia \\ Email: hammed@gmail.com \\ Avik Sinha \\ Department of General Management and Economics \\ Goa Institute of Management, India. \\ Email: avik@gmail.com
}

\begin{abstract}
The current study re-investigates the link between renewable power utilization, financial advancements, urbanization and carbon emanations by applying the newly introduced quantile autoregressive distributed lag (QARDL) method proposed by Cho et al. (2015) in Chinese economy. The framework is assessed utilizing quarterly data during the time span of 1970Q1-2017Q4. The outcomes confirm that the association between the variable is quantiledependent, which may uncover ambiguous outcomes in the previous research using out-dated estimations that mainly focus on the mean. The outcomes of Wald-test further confirmed the parameter constancy for China. Interestingly, we have found that on the one hand, renewable energy utilization helps in declining the $\mathrm{CO}_{2}$ emanations, and on the other hand, financial advancement and urbanization augments the $\mathrm{CO}_{2}$ emanations. Moreover, the causality analysis results divulge the existence of bidirectional causal associations between (a) renewable power and Carbon emanations, (b) financial advancements and Carbon emanations, and (c) urbanization and Carbon emanations. The findings recommended that government enforcement of renewable energy implementation should entail the introduction of cleaner production processes across the industries, so the level of environmental awareness helps the citizens in identifying the ecologically sustainable utilization patterns.
\end{abstract}

Keywords: Renewable energy, financial advancement, QARDL, China. 
In the era of industrialization, ascertaining sustainable development is gradually proving out to be one of the major problems being faced by the nations. There are several reasons behind such a claim, and these reasons can be attributed to the drivers of industrialization. The Paris Climate change summit focused on these issues, while the recent Sustainable Development Goals (SDG) Report $2018^{1}$ has stressed on these issues, for which the South Asian countries are gradually turning out to be laggards in attaining the SDG objectives. Policymakers in these nations are majorly interested in achieving economic growth, even at the cost of the socioecological balance (Sinha et al., 2019, 2020). Therefore, prevailing policies in these nations let industrialization to exert negative externality on the social and ecological balance, and thereby causing harm to the basis of sustainable development itself. Among these South Asian nations, China is the fastest growing economy, and because of its policy-level innovations, they are gradually gaining prominence in the global politico-economic scenario. As on 2018, the GDP growth rate of China is nearly 6.60 per cent, which is more than the double of the global average. This economic growth has been achieved through endogenous and exogenous innovations, which might have been catalyzed by the financial mobilization. Now, owing to this rise in the occupational prospects, Chinese cities have started experiencing a migration of labor force from rural areas to urban areas. Once this urbanization has set in, the Chinese cities have started facing issues regarding the pressure on urban infrastructure (Hsu, 2016). One of the major problems in this regard is the formation of shadow cities in the form of slum areas, and thereby, aggravating the pressure on the urban infrastructure (Jennings, 2018). Owing to the unsustainable usage of energy sources, these regions generate considerable amount of $\mathrm{CO}_{2}$ emissions from firewood and coal. Moreover, influx of population in urban centers gradually enhances the energy demand and vehicular congestion, which also amplify the $\mathrm{CO}_{2}$ emissions of China. UNDP (2012) already recognized this to be one of the major emerging problems in the Asia-Pacific countries, and this is turning out to be one of the major problems being faced by China in the recent years. China holds the highest percentage in terms of the global $\mathrm{CO}_{2}$ emissions in 2018 (World Bank, 2018), and this might create hindrance in the process of sustainable development of the nation.

While talking about the sustainable development, it is essential to discuss about the SDGs, which the nations around the globe need to comply by 2030 . Owing to the classic tradeoff between growth and development, South Asian nations are facing predicaments in the way to implement the SDG objectives, and China is no exception to that. Owing to the industrialization fuelled by financial development by means of credit channeling, and urbanization owing to centralization of vocational opportunities in urban centers, China is suffering from carbon emissions. In either of the conditions, the $\mathrm{CO}_{2}$ emissions are being caused by continuing reliance on the fossil fuel-based energy solutions. In order to attain a sustainable development, it might not be a pertinent solution, as according to the "Limits to Growth" approach by the Club of Rome, unceasing reliance on fossil fuel-based solutions for achieving economic growth can create a caveat on the growth trajectory (Meadows, 1974). Therefore, the nations around the globe are in the pursuit of alternate energy solutions, so that not only the rising energy demand can be fulfilled, but also the ecological quality can be sustained. Perhaps, owing to this particular reason, China is trying to increase the share of renewable energy solutions in its energy mix.

However, there lies the issue of policy level misalignment in China, because of which the full potential of renewable energy solutions are not being achieved by the citizens, and the level of ambient air pollution in the form of $\mathrm{CO}_{2}$ emissions is rising. This issue can be attributed

${ }^{1}$ https://www.un.org/development/desa/publications/the-sustainable-development-goals-report-2018.html 
to the policy level problems regarding the alignment of the energy and urban development policies, along with the industrial and banking policies. As the $\mathrm{CO}_{2}$ emissions in China can be considered a consequence of the industrial development trajectory, the role of financial development can never be ignored, as easy availability of credit is a boost for industrial development. Once this misalignment is in place, it is difficult for the policymakers to assure the availability of cost-effective green energy solution to the citizens (SDG 7), salvation of the ecological quality (SDG 13), and finally, maintaining a holistic well-being by means of creating vocational opportunities and thereafter, economic growth (SDG 8). Now, in order to fulfill this policy-level gap prevailing in China, it is required to understand the nature of associative movement between $\mathrm{CO}_{2}$ emissions, urbanization, financial development, and renewable energy consumption. There lies the focus of the present study.

The present study analyses the association between $\mathrm{CO}_{2}$ emissions, urbanization, financial development, and renewable energy consumption for China over the period of 19902017. Through this analysis, it is intended to address the policy level gap prevailing in China, so that a comprehensive policy framework can be designed by encompassing the SDG objectives to be addressed by China. As the policy framework to be suggested is targeted at the demand and supply sides of the industrialization, therefore, the associated SDG objectives need to be chosen carefully. The present study is aimed at designing a policy framework to address the SDG objectives, following which the allied energy and urban development policies will be aligned accordingly. Though the literature of energy and environmental economics has looked into this association at various temporal and contextual domains, the aspect of policy design for ascertaining sustainable development has been ignored largely, and there lies the contribution of the study. Designing a multipronged SDG framework for sustaining the industrial growth pattern is the first contribution of the study from the policy-designing perspective.

Apart from the contribution in the policy design front, this study also sheds light into the association from a methodological perspective. In the literature, this association has been visualized from a linear perspective, while considering model parameters at their respective medians. As the complexity in the global scenario is undergoing a transformation, it might be possible that different levels of one model parameter can have differential impacts on the different levels of the other model parameter. Moreover, because of the complexity of the global socio-economic and geo-political scenario, it might be assumed that the hypothesized association among the $\mathrm{CO}_{2}$ emissions, urbanization, financial development, and renewable energy consumption in China might be non-linear. This non-linearity in the associative movement among the parameters should be analyzed over both short run and long run period, and this associate movement needs to be analyzed across the numeric spectrum of the model parameters. This purpose has been fulfilled by the application of Quantile Autoregressive Distributed Lags (QARDL) method introduced by Cho et al. (2015). By applying the QARDL method, this paper checks the constancy of the long-haul connection over the quantiles and gives a versatile econometric view of the nonlinear behaviors at numerous central distributions. Contrasted with the basic ARDL method, the QARDL methods have the benefit of presenting potential asymmetries in the various levels of carbon emanations. In addition, the QARDL method is better than other nonlinear models, for instance, the Nonlinear-ARDL method, introduced by Shin et al. (2011), in which nonlinearity is exogenously described as the limit is set to zero as an alternative of being directed by an information-driven strategy. This methodological adaptation has brought forth the second contribution of the study.

The remainder of the paper is organized as pursues. Segment 2 quickly reviews the literature. Segment 3 clarifies the methodology and econometric detail. Segment 4 displays the 
data; while empirical results and interpretation are presented in Section 5, whereas conclusion and policy implications are shown in Section 6.

\section{Review of literature}

\subsection{Nexus between financial development and carbon emanations}

The process of advancements is beneficial or exerting positive effects on country's economic and financial stability, however, often criticized for generating ecological pressures. In this regard, Tang and Tan (2014) also examined the link of financial development (FD) in the form of foreign investment with environmental degradation. Studying the Malaysian economy between 1972 and 2009, the findings established that FD is positively linked to carbon emanation in Malaysia. This implied that expansion in foreign investment led to augment ecological degradation in the country. Using the panel approach, Zhang (2011) also explored the link between FD and environmental degradation in a panel of 24 emerging economies between 1980 and 2009. The empirical findings, similar to Tang and Tan (2014), established that rise in FD enhanced degradation in developing economies in the sampled period. Similar empirical evidence was found in the study of Shahzad et al. (2017) while examining the economy of Pakistan from the period of 1971 to 2011.

Conversely, Tamazian and Rao (2010) analyzed the connection between FD and carbon emanation for a panel of 24 developing economies from 1993 to 2004. The empirical results reported that FD is vital to influence carbon intensity. Nevertheless, unlike Tang and Tan (2014), the study revealed that rise in FD led to decline degradation by reducing carbon intensity in the studied developing economies. Similarly, Jalil and Feridun (2011) also investigated the connection between FD and environmental degradation in China from 1953 to 2006. Applying the measure of carbon dioxide emanation to reflect degradation, the study found that FD reduced the environmental pressures in Chinese economy. Moreover, Shahbaz et al. (2013) also studied the linkage between FD and environmental degradation in Indonesia from 1975 to 2011. Using the measure of carbon emanations to reflect degradation, the study reported that FD declined ecological burden by declining carbon emanation in Indonesian economy. Likewise, In Turkey, Salahuddin et al. (2018) analyzed the relationship of FD with carbon emanation from 1980 to 2013. For performing empirical estimation, the study used the method of ARDL analysis. The outcome of the investigation reported that FD persisted positive effects on carbon emanations. Consisting findings were also reported in the study of Saidi and Mbarek (2017) while examining the panel of nineteen developing nations from 1990 to 2013.

\subsection{Nexus between urbanization and carbon emanations}

The expansion of urban land and infrastructure is notably linked to improved economic development by carrying several positive effects in the form of improved living standards, convenience, efficiency, employment, and opportunities. On the other hand, urban development is often criticized for enhancing ecological burdens in the form of higher power consumption, resource depletion and excess commercialization (Maiti and Agrawal, 2005; Sinha et al., 2017). With the objective of testing the empirical link among urbanization and ecological degradation, Al-Mulali and Ozturk (2015) analyzed the association among the variables from 1996 to 2012. In order to perform empirical investigation, the investigation carried panel estimation for 14 MENA economies utilizing the methods of FMOLS. The empirical evidence found the vital role of urbanization in altering environmental stability. Particularly, the findings of the investigation study reported that urbanization augmented 
ecological burden of the sampled countries by carrying positive association with carbon emanations. Moreover, Liddle (2014) also studied the link between population and urbanization. Consistent with Al-Mulali and Ozturk (2015), the outcomes reported that Urbanization led to enhance ecological pressures by increasing carbon emanation.

In another investigation, Zhang et al. (2014) also studied the role of urbanization in affecting environmental stability in China from 1978 to 2011. The findings of empirical estimation also suggested the positive link between urban development and carbon emanations in China. Moreover, Wang et al. (2016) also analyzed the connection between urban growth and ecological degradation in top ASEAN countries from 1980 to 2009. For empirical estimations, the authors applied the methods of FMOLS. The outcomes of the empirical investigation reported that urban development is significant to augment ecological deterioration indicating that rise in urbanization enhance carbon emanation in ASEAN economies. Moreover, Al-Mulali et al. (2012) also explored the contribution of urbanization in leading ecological degradation from 1980 to 2008. Using the panel of global economies, the study applied the method of FMOLS to investigate the presence of empirical link. Similar to Wang et al. (2016), the empirical results reported the significant relationship among the variables. Particularly, the outcomes found that urbanization increased carbon discharge in eighty-four percent of the studied economies. More recently, Shahbaz et al. (2019) analyzed the dynamic connection between urban growth and ecological degradation in Vietnam. For this, the authors studied the economy from the period of 1974 to 2016 . The findings of the empirical results established that urban development does not influence carbon emanation in short run. As for long run estimations, the empirical evidence reported contradictory findings. Unlike, Al-Mulali and Ozturk (2015), Zhang et al. (2014) and Al-Mulali et al. (2012), the outcomes of the study established the negative association between urban development and carbon emanations. This implied that expansion in urbanization led to decline environmental quality in Vietnam by enhancing the levels of carbon emanations. Finally, the study found the feedback causal link between urban development and environmental degradation in the country.

\subsection{Nexus between renewable energy and carbon emanations}

The relationship of green energy with greenhouse gases is notable for providing solutions to environmental degradation. In this regard, many studies focused on the potentials of renewable energy to decline the levels of carbon emanations. Among them, Dogan and Seker (2016a) explored the dynamic connection between the variables in top renewable consumed economies from 1985 to 2011. Utilizing heterogeneous panel approach, the outcome reported the significant link between renewable energy utilization and carbon emanation. Specifically, the findings reported that rise in the usage of renewable power assisted to reduce carbon levels in the sampled economies. In another similar study, Dogan and Seker (2016b) examined the link between renewable and non-renewable power to influence toxic emanations in the form of carbon emanation in the European economies. Using the data of thirty-three years, the results established that renewable power utilization is potential to decline carbon emanation in the European countries. On the other hand, the findings stated that non-renewable power enhanced the carbon intensity in the sampled economies.

In another Panel investigation, Apergis and Payne (2015) investigated the connection between renewable power and carbon emanation from 1980 to 2010 in eleven South American economies. The outcomes of the study found the bi-directional association between renewable energy and carbon emanation in the sampled countries. Moreover, Bilgili et al. (2016) analyzed 
the association between renewable energy utilization and carbon emanations in seventeen OECD nations from 1977 to 2010. Similar to Dogan and Seker (2016a), the findings of the investigation, applying the methods of FMOLS and DOLS approaches, stated that renewable power is significant to decline carbon emanation in the sampled countries. More recently, Sharif et al. (2019) examined the association of renewable and non-renewable power with greenhouse gas emanation in the panel of seventy-four countries from 1990 to 2015. The outcomes of empirical investigation using heterogeneous Panel Approach revealed that renewable power is significant to reduce ecological degradation in the studied sample. Shahbaz and Sinha (2019) have provided a detailed review on this aspect.

\section{Methodology}

\subsection{Quantile autoregressive unit root test}

The quantile autoregressive unit root test is employed by researchers to test the stationary properties of the series in term of their conditional means and the conditional distribution of the quantile. The Quantile Auto-Regressive (QAR) unit root test is an advanced form of unit root test considered by Koenker and Xiao (2004) and modified by Galvao (2009) by including linear time and covariates into the model. To model Quantile Auto-Regressive (QAR) unit root, $Y_{t}$ denoted as the strict stationary with a past information set $\left.I_{t}^{Y}=\left(Y_{t-1}, \ldots \ldots \ldots Y_{t-S}\right)^{\prime}\right) \epsilon R^{S}$. The study assumes $F_{Y}\left(. / I_{t}^{Y}\right)$ as the conditional distribution function of $Y t$ given $I_{t}^{Y}$. The QAR unit root is estimated based on linear QR stated as thus:

$$
Q_{T}^{Y}\left(Y_{\dot{t} .} \backslash I_{t}^{Y}=U_{i}(\tau)+\mu_{2}(\tau) t+\propto(\tau) Y_{\dot{t}-1}+\sum_{j=1}^{p} \propto_{J}(\tau) Y_{i-j}+F_{\mu}^{-1(\tau)}\right.
$$

According to Galvao (2009) and Koenker and Xiao (2004) estimated t-statistics for different quantiles $\tau \varepsilon T$ to examine the null hypothesis $H_{0}: \alpha(\tau)=1$ and Quantile AutoRegressive QAR model followed t-statistics.

\subsection{Quantile ARDL model}

In order to examine the cointegration (long-run association) among renewable energy, financial advancement, urbanization for $\mathrm{CO}_{2}$ emanation in China across different quantiles, this study employed the newly developed Quantile ARDL model developed by Cho et al. (2015). The rationale behind the QARDL model is that it tests the quantile long-run equilibrium influence of renewable energy, financial advancement on $\mathrm{CO}_{2}$ emanations. As stated earlier, the QARDL model allows us to investigate the long-term equilibrium impact of renewable energy, urbanization as well as financial advancement on $\mathrm{CO}_{2}$ Emanation along for different quantiles. Further, the Wald test allows us to examine the time-varying integration association among the variables used, in which the constancy of integrating coefficients across the quantiles can be checked. Given a linear ARDL model, we specified our model as follows:

$$
C O 2_{t}=\mu+\sum_{i=1}^{p} \varphi_{i} C O 2_{t-i}+\sum_{i=0}^{q} \emptyset_{i} R E_{t-i}+\sum_{i=0}^{m} a_{i} F D_{t-i}+\sum_{i=0}^{n} b_{i} U R B_{t-i}+U_{t}
$$

$$
\begin{aligned}
& \text { Note that } U_{t} \text { is the error term which is defined as } C O 2_{t}-\mathrm{E}\left[C O 2_{t} / \Omega_{1-1}\right] \text {, with } \Omega_{1-1} \\
& \text { the } \text { smallest }_{\text {being }} \begin{array}{c}
\sigma-\text { field } \\
\left\{C O 2_{t}, R E_{t}, F D_{t}, U R B_{t}, C O 2_{t-1}, R E_{t-1}, F D_{t-1}, U R B_{t-1} \ldots\right\}
\end{array} \text { and } \mathrm{p}, \mathrm{q}, \mathrm{m} \text {, and } \mathrm{n} \text { are lag orders. } \\
& C O 2_{t}, R E_{t}, F D_{t}, U R B_{t} \text { represent } \mathrm{CO}_{2} \text { emanation, renewable energy, financial advancement, and }
\end{aligned}
$$


urbanization in China, respectively, at a particular period. We then extended Eq. (2) to a quantile context to the following form of the QARDL model:

$$
\begin{aligned}
& Q_{C O 2_{t}}=\mu(\tau)+\sum_{i=1}^{p} \varphi_{i}(\tau) C O 2_{t-i}+\sum_{i=0}^{q} \emptyset_{i}(\tau) R E_{t-i}+\sum_{i=0}^{m} a_{i}(\tau) F D_{t-i}+ \\
& \sum_{i=0}^{n} b_{i}(\tau) U R B_{t-i}+U_{t}(\tau)
\end{aligned}
$$

Where $U_{t}(\tau)=\mathrm{CO}_{t}-Q_{t \mathrm{CO}_{t}}\left(\tau / \Omega_{1-1}\right)$ (see Kim \& white, 2003), and $0<\tau<1$ is the quantile. Note: the following set of quantiles could be considered; $\tau \in$ $\{0.05,0.1,0.2,0.3,0.4,0.5,0.6,0.7,0.8,0.9 \& 0.95\}$. To guard against any probable serial correlation in the error term, Eq. (3) could be further generalized as:

$$
\begin{aligned}
& Q_{\triangle C O 2_{t}}=\mu(\tau)+\rho C O 2_{t-i}+\gamma R E_{t-i}+\delta F D_{t-i}+\vartheta U R B_{t-i}+\sum_{i=1}^{p} \varphi_{i}(\tau) C O 2_{t-i}+ \\
& \sum_{i=0}^{q} \emptyset_{i}(\tau) R E_{t-i}+\sum_{i=0}^{m} a_{i}(\tau) F D_{t-i}+\sum_{i=0}^{n} b_{i}(\tau) U R B_{t-i}+U_{t}(\tau)
\end{aligned}
$$

According to Cho et al. (2015), Eq (4) could be re-formulated to give the following ECM re-parameterization of the QARDL model;

$$
\begin{aligned}
& Q_{\triangle C O 2_{t}}=\mu(\tau)+\rho .(\tau)\left(C O 2_{t-1}-\beta .(\tau) R E_{t}\right)+\rho .(\tau)\left(C O 2_{t-1}-\beta .(\tau) F D_{t}\right)+ \\
& \rho .(\tau)\left(C O 2_{t-1}-\beta .(\tau) . U R B_{t}\right)+\sum_{i=1}^{p-1} \varphi_{i}(\tau) \Delta C O 2_{t-i}+\sum_{i=0}^{q-1} \emptyset_{i}(\tau) \Delta R E_{t-i}+ \\
& \sum_{i=0}^{m-1} a_{i}(\tau) \Delta F D_{t-i}+\sum_{i=0}^{n-1} b_{i}(\tau) \Delta U R B_{t-i}+U_{t}(\tau)
\end{aligned}
$$

The cumulative short-run influence of the earlier value of each of the independent variables on its current value is measured by $\varphi^{*}=\sum_{i=0}^{p-1} \varphi_{i}$, the cumulative short-run impact of the contemporaneous and previous value of RE, FD, and URB on the current value of $\mathrm{CO}_{2}$ emanation is measured by $\emptyset *=\sum_{i=0}^{q-1} \emptyset_{i}, a *=\sum_{i=0}^{m-1} a_{i}, b *=\sum_{i=0}^{n-1} b_{i}$. Similarly, the long run cointegrating parameter $\beta$ is estimated as $\beta=\frac{-(\gamma+\delta+\vartheta)}{\rho^{*}}$ such that the rate of convergence $\rho$ in Eq (5) is negative and significant. Finally, in order to examine the long-run and short-run asymmetric impact of renewable energy, financial advancement, and urbanization on $\mathrm{CO}_{2}$ emanations, the study performs the Wald-test to examine the following null hypotheses for the short-run and long-run asymmetry, respectively:

$H_{0}^{1}=\beta(0.05)=\beta(0.1)=\ldots . . \beta(0.95)$ Against the alternative $\exists i \neq \frac{j}{\beta(i)} \neq \beta(j)$

$H_{0}^{s}=\varnothing(0.05)=\varnothing(0.1)=\ldots . . \varnothing(0.95)$, etc. Against the alternative $\exists i \neq \frac{j}{\emptyset(i)} \neq \varnothing(j)$

\subsection{Quantile causality test}

To examine the direction of causality between the variables of the study (renewable energy, financial advancement, urbanization, and carbon dioxide emanation), the following bivariate $\operatorname{VAR}(\mathrm{p})$ model is estimated:

$$
\begin{aligned}
& C O 2_{t}=\alpha_{1}+\sum_{i=1}^{p} \beta_{i} C O 2_{t-i}+\sum_{i=1}^{p} \emptyset_{i} R E_{t-i}+\sum_{i=1}^{p} a_{i} F D_{t-i}+\sum_{i=1}^{p} b_{i} U R B_{t-i}+U_{1} t \\
& R E_{t}=\alpha_{2}+\sum_{i=1}^{p} \gamma_{i} R E_{t-i}+\sum_{i=1}^{p} \pi_{i} C O 2_{t-i}+\sum_{i=1}^{p} c_{i} F D_{t-i}+\sum_{i=1}^{p} \delta_{i} U R B_{t-i}+U_{2} t \\
& F D_{t}=\alpha_{3}+\sum_{i=1}^{p} f_{i} F D_{t-i}+\sum_{i=1}^{p} g_{i} R E_{t-i}+\sum_{i=1}^{p} h_{i} C O 2_{t-i}+\sum_{i=1}^{p} k_{i} U R B_{t-i}+U_{3} t \\
& U R B_{t}=\alpha_{4}+\sum_{i=1}^{p} m_{i} U R B_{t-i}+\sum_{i=1}^{p} n_{i} C O 2_{t-i}+\sum_{i=1}^{p} p_{i} R E_{t-i}+\sum_{i=1}^{p} q_{i} F D_{t-i}+U_{4} t
\end{aligned}
$$


Where, $U_{1}, U_{2}, U_{3}, U_{4}$, are serially uncorrelated and Equation (6), (7), (8), and (9) and those of quantile causality test running from the independent variables to the dependent variable. We fail to reject the null hypothesis that $\mathrm{CO}_{2}$ emanation does not cause each of the independent variables if $\emptyset_{1}=\emptyset_{2}=\ldots . \emptyset_{p}=0$; if $\pi_{1}=\pi_{2}=\cdots . \pi_{p}=0$., if $g_{1}=g_{2}=\cdots . g_{p}=0$., and if $m_{1}=m_{2}=\cdots \cdot m_{p}=0$. Note that by extending the conventional Granger causality test to a quantile form, $\mathrm{CO}_{2}$ does not Granger cause each of the independent variables at quantile $\tau$ vis $-\mathrm{a}$ - vis the available information at a time, $\mathrm{t}$;

$$
\Omega_{1}=C O 2_{t-1}, C O 2_{t-2,} \mathrm{CO}_{t-3, \ldots}, \mathrm{CO}_{t-P} ; R E_{t-1}, R E_{t-2, \ldots,} R E_{t-P}, \text { etc. 'If' }\left\{X^{2}{ }_{t}{ }\right.
$$

$\left.\left.X_{t-1}, X_{t-2}, \ldots \ldots X_{t-p}, Y_{t-1}, Y_{t-2, \ldots \ldots \ldots .,} Y_{t-P}\right\}=Q_{t}\left\{X_{t} / X_{t-1}, X_{t-2}, \ldots . X_{t-p}\right\} X_{t-p}\right\}$ and $\mathrm{Y}$ causes $X$ at the quantile $\tau$ if : $Q_{t}\left\{X_{t} / X_{t-1}, X_{t-2}, \ldots . X_{t-p}, Y_{t-1}, Y_{t-2, \ldots \ldots \ldots . . .,} Y_{t-P}\right\} \neq$ $Q_{t}\left\{X_{t} / X_{t-1}, X_{t-2}, \ldots . X_{t-p}, Y_{t-1}, Y_{t-2, \ldots \ldots \ldots . .,} Y_{t-P}\right\}$, where $: Q_{t}\left\{X_{t} /.\right\}$ is the $\tau$ quantile of $\mathrm{X}$; and $\mathrm{O}<\tau<1$. The $\tau-$ quantile causality from $\mathrm{X}$ to $\mathrm{Y}$ is examined in a similar manner.

\section{Data description}

In the present study, data for per capita of renewable energy utilization (kg of oil equivalent), and per capita of carbon dioxide emanation (kilotons of oil equivalent) have been retrieved from the OECD database. Following Shahbaz and Lean (2012), the current study uses domestic credit to the private sector as a proxy of financial advancement and urban population as a share of the total population is the proxy for urbanization. Data for these two variables have been retrieved from World Development Indicators (World Bank, 2018). In the analysis, we used quarterly of China spanning from the period of 1970Q1-2017Q4. The study converted the annual data into quarter frequency utilizing a quadratic match-sum method following Cheng et al. (2012), Sbia et al. (2014), Shahbaz et al. (2017, 2018), and Sharif et al. (2019). This procedure allows seasonal deviations to be adjusted by converting the data from low to high frequency via dropping the point to point data deviations (Sharif et al. 2019; Arain et al. 2019; Sharif et al. 2020).

\begin{tabular}{|l|l|r|r|r|r|r|}
\hline Table-1: Descriptive statistics \\
\hline Variables & \multicolumn{1}{|c|}{ Mean } & \multicolumn{1}{|c|}{ Min. } & \multicolumn{1}{c|}{ Max. } & Std. Dev. & J-B Stats & Correlation \\
\hline Renewable Energy & 51.371 & 66.813 & 38.809 & 5.871 & $16.337^{* * *}$ & $-0.793^{* * *}$ \\
\hline Financial Advancement & 99.789 & 202.901 & 36.149 & 51.193 & $15.770^{* * *}$ & $0.882^{* * *}$ \\
\hline Urbanization & 22.491 & 39.317 & 8.570 & 8.550 & $18.177^{* * *}$ & $0.969^{* * *}$ \\
\hline Carbon Dioxide Emanation & 1038.348 & 2575.319 & 213.024 & 788.956 & $29.868^{* * *}$ & - \\
\hline Note: *** indicates that variables are significant at 1\% level of significance \\
\hline
\end{tabular}

Table-1 reports the descriptive statistics of Renewable Energy, Financial Advancement, Urbanization, and $\mathrm{CO}_{2}$ Emanation. On a yearly basis, the average Renewable Energy, in China amounts to 51.371 kilowatt-hour $(\mathrm{kWh})$ which less than the world average, while Financial Advancement is quite high amounted to 99.789 per firms with a bank loan or line of credit (\%), however, Urbanization is low compared with Financial Advancement and Renewable Energy. Urbanization amounted to 22.491 percent per total population living in urban areas, and Carbon Dioxide Emanation is 1038.348 metric tons per capita. $\mathrm{CO}_{2}$ Emanation highest variability as indicated by the high value of standard deviation. Also, the large standard deviation is observed from financial advancement. Furthermore, all the four-time series variables are positively

\footnotetext{
${ }^{2}$ For simplicity in the equations, $\mathrm{Y}$ is occasionally used to represent $\mathrm{CO}_{2}$; $\mathrm{X}$ represents each of $\mathrm{RE}, \mathrm{FD}$ and URB
} 
332 skewed, and evidence of excess kurtosis is also shown, this indicates that they have a longer 333 right and fatter tails than a normal distribution. Therefore, the null hypothesis of the Jarque334 Bera (JB) test for normality is rejected. The results of JB test confirm that the data is non335 normal indicating a presence of nonlinearity among the variables, so in this case, quantile 336 estimations are recommended (Troster et al. 2018; Sharif et al. 2019; Mishra et al. 2019).

\section{5. Empirical results and discussion}

338 Before QARDL model is estimated, it is highly imperative to know the order of integration of 339 the series as it gives validity for modeling QARDL. Therefore, the researcher presents the 340 Quantile unit root in Table 2. The estimates of persistence and the t-statistics for the null 341 hypothesis are illustrated from the Quantile Unit Root Test postulated as thus: $H_{0}: \mathrm{a}(\tau)=1$ for 342 Eq. (1) for the grid of 19 quantiles $\mathrm{T}=\{0.05: 0.95\}$. The 10 lags of the endogenous variable are 343 used to overcome serial correlation. Evident from QARDL unit root showed that renewable 344 energy, financial advancement, urbanization, and carbon dioxide emanation for different 345 conditional distribution quantiles have a unit root (i.e., not stationary at level). The results of 346 the unit root test confirmed that all the variables are showing non-stationary behavior at level 347 series (Table-2), i.e. renewable energy consumption, financial advancement, urbanization, and 348 carbon dioxide emanation are non-stationary at the 5\% significance level for all the quantiles 349 of the conditional distribution. All the variables are non-stationary at the high quantiles of the 350 distribution. Therefore, the null hypothesis of unit root is rejected at the $5 \%$ significance level.

\begin{tabular}{|c|c|c|c|c|c|c|c|c|c|c|c|c|}
\hline \multicolumn{13}{|c|}{ Table-2: Results of the Quantile Unit Root test } \\
\hline \multirow{2}{*}{ Quantiles } & \multicolumn{3}{|c|}{ RE } & \multicolumn{3}{|c|}{ FD } & \multicolumn{3}{|c|}{ URB } & \multicolumn{3}{|c|}{$\mathrm{CO}_{2}$} \\
\hline & $\alpha(\tau)$ & t-stats & C.V & $\alpha(\tau)$ & t-stats & C.V & $\alpha(\tau)$ & t-stats & C.V & $\alpha(\tau)$ & t-stats & C.V \\
\hline 0.10 & 0.899 & -1.765 & -2.849 & 0.709 & -1.140 & -2.385 & 0.831 & -2.515 & -2.754 & 0.932 & -0.987 & -2.779 \\
\hline 0.15 & 0.871 & -2.330 & -3.007 & 0.742 & -0.609 & -2.385 & 0.829 & -2.523 & -2.765 & 0.975 & -0.572 & -2.922 \\
\hline 0.25 & 0.839 & -2.724 & -2.784 & 0.885 & -0.303 & -2.385 & 0.831 & -2.282 & -3.096 & 0.863 & -1.848 & -3.105 \\
\hline 0.30 & 0.859 & -2.564 & -2.853 & 0.884 & -0.025 & -2.385 & 0.862 & -2.347 & -3.042 & 0.912 & -1.249 & -3.075 \\
\hline 0.35 & 0.863 & -2.485 & -2.865 & 0.945 & 1.141 & -2.385 & 0.829 & -1.603 & -3.104 & 0.871 & -1.662 & -3.092 \\
\hline 0.40 & 0.891 & -2.008 & -2.861 & 0.956 & 1.373 & -2.385 & 0.876 & -1.679 & -3.154 & 0.858 & -1.720 & -3.098 \\
\hline 0.45 & 0.894 & -1.969 & -2.561 & 0.966 & 1.428 & -2.438 & 0.966 & -1.593 & -3.240 & 0.796 & -2.300 & -3.201 \\
\hline 0.65 & 0.913 & -1.618 & -2.385 & 1.006 & 2.439 & -2.571 & 0.864 & -0.710 & -3.054 & 0.838 & -1.803 & -2.910 \\
\hline 0.70 & 0.942 & -1.516 & -2.444 & 0.981 & 1.898 & -2.537 & 0.863 & -1.370 & -2.983 & 0.803 & -1.908 & -2.877 \\
\hline 0.75 & 0.901 & -1.721 & -2.463 & 1.033 & 1.636 & -2.385 & 0.860 & 0.017 & -2.842 & 0.789 & -2.370 & -2.939 \\
\hline 0.80 & 0.896 & -1.846 & -2.500 & 1.059 & 1.975 & -2.480 & 0.923 & 0.614 & -2.775 & 0.773 & -2.688 & -2.850 \\
\hline 0.85 & 0.850 & -2.159 & -2.434 & 1.107 & 2.919 & -2.464 & 1.035 & 1.861 & -2.692 & 0.780 & -2.479 & -2.715 \\
\hline 0.90 & 0.874 & -2.194 & -2.385 & 1.058 & 2.916 & -2.385 & 1.072 & 0.435 & -2.464 & 0.739 & -2.118 & -2.542 \\
\hline 0.95 & 0.890 & -2.082 & -2.385 & 1.104 & 5.544 & -2.385 & 0.931 & 0.988 & -2.650 & 0.768 & -2.268 & -2.385 \\
\hline
\end{tabular}

Notes: The table shows point estimates, t-statistics, and critical values for the $5 \%$ significance level. If the $t-$ statistic is numerically smaller than the critical value, so we reject the null hypothesis of $\alpha(\tau)=$ one at the $5 \%$ level.

Source: Author Estimations 
The evidence from Table- 3 showed that the $\rho *$ (estimated parameter) is highly significant, with the expected negative sign at all quantiles, a strong evidence of cointegration between renewable energy, financial advancement, urbanization, and carbon dioxide emanation, subsequently the speed of adjustment coefficient $\rho *$ for this country is significantly at all the quantiles $(0.05-0.95)$ and negative, hence having the required negative sign. In specific, the speed of the adjustment coefficient is -0.253 , the negative sign and significance indicate the stability of the estimated ARDL model, i.e., there is convergence to the long-run equilibrium. Further, the past variations of $\mathrm{CO}_{2}$ emanations have a positive cumulative and significant impact on present values of $\mathrm{CO}_{2}$ emanations (0.747), whereas present and past variations of renewable energy, financial advancement, and urbanization show a positive cumulative and significant impact on the present level of $\mathrm{CO}_{2}$ emanations. Our result is in line with those of Pata (2018) and Wang et al. (2018), who found similar results for Turkey and the G-20 economies, respectively. Moreover, long-run cointegrating coefficient $\beta$ is significant at all quantiles $(0.05-0.95)$. However, $\beta \operatorname{RENE}(\tau)$ remains positive at the considered low quantiles to middle quantiles [0.05-0.50] and turn negative after [0.50-0.95]. Conversely, the coefficient of $\beta \mathrm{FD}(\tau)$ and $\beta \mathrm{URB}(\tau)$ is positive and significant in all the quantiles [0.05-0.95]. However, the short-run results confirm the cumulative effect of past variations of $\mathrm{CO}_{2}$ emanations on their current level is positive and significant at all quantiles. Therefore, it is worth noting that the lagged variations of $\mathrm{CO}_{2}$ emanations lead to an increase (decrease) of their current level. The result indicates that renewable energy increases $\mathrm{CO}_{2}$ emanations significantly at 0.05 to 0.50 quantiles. However, it reduces $\mathrm{CO}_{2}$ emanation after middle quantiles in China. Additionally, the influence of financial advancement variations with time declines $\mathrm{CO}_{2}$ emanations after the middle quantile to high quantiles. Conversely, financial advancement and urbanization increase $\mathrm{CO}_{2}$ emanation from lower quantile to high quantiles. The model is used by Zaidi et al. (2019) to investigate the financial advancement and $\mathrm{CO}_{2}$ emanations in Asia Pacific Economic Cooperation (APEC) economies. Similarly, the long run connection between $\mathrm{CO}_{2}$ emanation per capita, financial advancement and renewable energy is established by Cheng et al. (2019) in the BRICS countries.

The study results for the corresponding Wald tests (Table-4) have shown rejection of the null of linearity (i.e., parameter constancy) of the speed of adjustment parameter. This indicates that renewable energy, financial advancement, urbanization, and carbon dioxide emanation converged to long-run equilibrium in China. It explained 12 percent long-run equilibrium amid renewable energy, financial advancement, and urbanization to and carbon dioxide emission. Nevertheless, the study failed to accept the coefficient of constancy hypothesis across the quantiles for the long run, integrating co-efficient $\beta R E N E$ in China. This shows the evidence of dynamism in different quantiles in China for the cointegrating parameter between renewable energy and $\mathrm{CO}_{2}$ emanation. 


\begin{tabular}{|c|c|c|c|c|c|c|c|c|c|c|c|}
\hline $\begin{array}{c}\text { Quantiles } \\
(\tau)\end{array}$ & $\alpha_{*}(\tau)$ & $\rho_{*}(\tau)$ & $\beta_{\text {RENE }}(\tau)$ & $\beta_{\mathrm{FD}}(\tau)$ & $\beta_{\text {URB }}(\tau)$ & $\varphi_{1}(\tau)$ & $\omega_{0}(\tau)$ & $\omega_{1}(\tau)$ & $\lambda_{0}(\tau)$ & $\lambda_{1}(\tau)$ & $\theta_{0}(\tau)$ \\
\hline 0.05 & $\begin{array}{r}-0.137 * * * \\
(0.034)\end{array}$ & $\begin{array}{r}-0.253^{* * *} \\
(0.093)\end{array}$ & $\begin{array}{r}0.352 * * * \\
(0.002)\end{array}$ & $\begin{array}{r}0.284 * * * \\
(0.013)\end{array}$ & $\begin{array}{r}0.826^{* * * *} \\
(0.001)\end{array}$ & $\begin{array}{r}1.022 * * * \\
(0.219)\end{array}$ & $\begin{array}{r}-0.022 * * * \\
(0.005)\end{array}$ & $\begin{array}{r}-0.016^{* * *} \\
(0.003)\end{array}$ & $\begin{array}{r}0.193 \\
(0.162) \\
\end{array}$ & $\begin{array}{r}0.059 \\
(0.129) \\
\end{array}$ & $\begin{array}{r}0.291 \\
(0.221) \\
\end{array}$ \\
\hline 0.10 & $\begin{array}{r}-0.198 * * * \\
(0.065) \\
\end{array}$ & $\begin{array}{r}-0.298 * * * \\
(0.077) \\
\end{array}$ & $\begin{array}{r}0.319 * * * \\
(0.008) \\
\end{array}$ & $\begin{array}{r}0.273 * * * \\
(0.019) \\
\end{array}$ & $\begin{array}{r}0.839 * * * \\
(0.004)\end{array}$ & $\begin{array}{r}1.068 * * * \\
(0.237) \\
\end{array}$ & $\begin{array}{r}-0.022 * * * \\
(0.005) \\
\end{array}$ & $\begin{array}{r}-0.006 * * * \\
(0.001) \\
\end{array}$ & $\begin{array}{r}0.173 \\
(0.136) \\
\end{array}$ & $\begin{array}{r}0.062 \\
(0.122) \\
\end{array}$ & $\begin{array}{r}0.331 \\
(0.204) \\
\end{array}$ \\
\hline 0.20 & $\begin{array}{r}-0.185^{* * *} * \\
(0.045)\end{array}$ & $\begin{array}{r}-0.262 * * * \\
(0.059)\end{array}$ & $\begin{array}{r}0.278 * * * \\
(0.012)\end{array}$ & $\begin{array}{r}0.253 * * * \\
(0.022)\end{array}$ & $\begin{array}{r}0.864 * * * \\
(0.0011)\end{array}$ & $\begin{array}{r}1.057 * * * \\
(0.190)\end{array}$ & $\begin{array}{r}-0.022 * * * \\
(0.005)\end{array}$ & $\begin{array}{r}-0.013 * * * \\
(0.004)\end{array}$ & $\begin{array}{r}0.171 \\
(0.153) \\
\end{array}$ & $\begin{array}{r}0.061 \\
(0.121) \\
\end{array}$ & $\begin{array}{l}0.385^{*} \\
(0.201) \\
\end{array}$ \\
\hline 0.30 & $\begin{array}{r}-0.164 * * \\
(0.079) \\
\end{array}$ & $\begin{array}{r}-0.269 * * * \\
(0.064) \\
\end{array}$ & $\begin{array}{r}0.253 * * * \\
(0.017) \\
\end{array}$ & $\begin{array}{r}0.217 * * * \\
(0.017)\end{array}$ & $\begin{array}{r}0.891 * * * \\
(0.0016)\end{array}$ & $\begin{array}{r}1.119 * * * \\
(0.179)\end{array}$ & $\begin{array}{r}-0.022 * * * \\
(0.005)\end{array}$ & $\begin{array}{r}-0.014 * * * \\
(0.004) \\
\end{array}$ & $\begin{array}{r}0.158 \\
(0.166) \\
\end{array}$ & $\begin{array}{r}0.061 \\
(0.117) \\
\end{array}$ & $\begin{array}{r}0.423 * * \\
(0.197) \\
\end{array}$ \\
\hline 0.40 & $\begin{array}{r}-0.143^{* *} \\
(0.069) \\
\end{array}$ & $\begin{array}{r}-0.273 * * * \\
(0.043) \\
\end{array}$ & $\begin{array}{r}0.202 * * * \\
(0.012) \\
\end{array}$ & $\begin{array}{r}0.208 * * * \\
(0.009) \\
\end{array}$ & $\begin{array}{r}0.912 * * * \\
(0.0021) \\
\end{array}$ & $\begin{array}{r}1.172 * * * \\
(0.132) \\
\end{array}$ & $\begin{array}{r}-0.026 * * * \\
(0.004) \\
\end{array}$ & $\begin{array}{r}-0.014 * * * \\
(0.004) \\
\end{array}$ & $\begin{array}{r}0.184 \\
(0.167) \\
\end{array}$ & $\begin{array}{r}0.058 \\
(0.112) \\
\end{array}$ & $\begin{array}{r}0.474 * * \\
(0.185) \\
\end{array}$ \\
\hline 0.50 & $\begin{array}{c}-0.179 * \\
(0.092)\end{array}$ & $\begin{array}{r}-0.279 * * * \\
(0.074)\end{array}$ & $\begin{array}{r}0.183^{* * * *} \\
(0.002)\end{array}$ & $\begin{array}{r}0.197 * * * \\
(0.006)\end{array}$ & $\begin{array}{r}0.946^{* * *} * \\
(0.0035)\end{array}$ & $\begin{array}{r}1.179 * * * \\
(0.139)\end{array}$ & $\begin{array}{r}-0.026 * * * \\
(0.004)\end{array}$ & $\begin{array}{r}-0.014 * * * \\
(0.004)\end{array}$ & $\begin{array}{r}0.221 \\
(0.153) \\
\end{array}$ & $\begin{array}{r}0.052 \\
(0.107) \\
\end{array}$ & $\begin{array}{r}0.529 * * * \\
(0.178) \\
\end{array}$ \\
\hline 0.60 & $\begin{array}{r}-0.202 * * \\
(0.097) \\
\end{array}$ & $\begin{array}{r}-0.284 * * * \\
(0.003) \\
\end{array}$ & $\begin{array}{r}-0.363^{* * *} * \\
(0.001) \\
\end{array}$ & $\begin{array}{r}0.227 * * * \\
(0.003)\end{array}$ & $\begin{array}{r}0.978 * * * \\
(0.004) \\
\end{array}$ & $\begin{array}{r}1.183^{* * * *} \\
(0.143) \\
\end{array}$ & $\begin{array}{r}-0.021 * * * \\
(0.003) \\
\end{array}$ & $\begin{array}{r}-0.014 * * * \\
(0.004)\end{array}$ & $\begin{array}{r}0.232 \\
(0.152) \\
\end{array}$ & $\begin{array}{r}0.047 \\
(0.098) \\
\end{array}$ & $\begin{array}{r}0.575 * * * \\
(0.171) \\
\end{array}$ \\
\hline 0.70 & $\begin{array}{r}-0.263^{* *} \\
(0.118) \\
\end{array}$ & $\begin{array}{r}-0.289^{* * *} \\
(0.018) \\
\end{array}$ & $\begin{array}{r}-0.391 * * * \\
(0.006) \\
\end{array}$ & $\begin{array}{r}0.287 * * * \\
(0.013)\end{array}$ & $\begin{array}{r}1.045^{* * * *} \\
(0.089)\end{array}$ & $\begin{array}{r}1.197 * * * \\
(0.159)\end{array}$ & $\begin{array}{r}-0.020 * * * \\
(0.003) \\
\end{array}$ & $\begin{array}{r}-0.017 * * * \\
(0.007) \\
\end{array}$ & $\begin{array}{r}0.263^{* *} \\
(0.110) \\
\end{array}$ & $\begin{array}{r}0.043 \\
(0.086) \\
\end{array}$ & $\begin{array}{r}0.627 * * * \\
(0.165)\end{array}$ \\
\hline 0.80 & $\begin{array}{r}-0.233^{* *} \\
(0.103) \\
\end{array}$ & $\begin{array}{r}-0.291 * * * \\
(0.001) \\
\end{array}$ & $\begin{array}{r}-0.451 * * * \\
(0.011) \\
\end{array}$ & $\begin{array}{r}0.305^{* * * *} \\
(0.019) \\
\end{array}$ & $\begin{array}{r}1.022 * * * \\
(0.077)\end{array}$ & $\begin{array}{r}1.125^{* * *} \\
(0.174) \\
\end{array}$ & $\begin{array}{r}-0.027 * * * \\
(0.002)\end{array}$ & $\begin{array}{r}-0.024 * * * \\
(0.004) \\
\end{array}$ & $\begin{array}{r}0.289 * * * \\
(0.094)\end{array}$ & $\begin{array}{r}0.038 \\
(0.083) \\
\end{array}$ & $\begin{array}{r}0.693 * * * \\
(0.142)\end{array}$ \\
\hline 0.90 & $\begin{array}{r}-0.275^{* * *} * \\
(0.063)\end{array}$ & $\begin{array}{r}-0.297 * * * \\
(0.008)\end{array}$ & $\begin{array}{r}-0.571 * * * \\
(0.013)\end{array}$ & $\begin{array}{r}0.342 * * * \\
(0.044)\end{array}$ & $\begin{array}{r}1.033 * * * \\
(0.063)\end{array}$ & $\begin{array}{r}1.212 * * * \\
(0.245)\end{array}$ & $\begin{array}{r}-0.029 * * * \\
(0.005)\end{array}$ & $\begin{array}{r}-0.029 * * * \\
(0.005)\end{array}$ & $\begin{array}{r}0.295 * * * \\
(0.091)\end{array}$ & $\begin{array}{r}0.035 \\
(0.079)\end{array}$ & $\begin{array}{r}0.753 * * * \\
(0.112)\end{array}$ \\
\hline 0.95 & $\begin{array}{r}-0.269 * * * \\
(0.079)\end{array}$ & $\begin{array}{r}-0.301 * * * \\
(0.041)\end{array}$ & $\begin{array}{r}-0.631 * * * \\
(0.035)\end{array}$ & $\begin{array}{r}0.271 * * * \\
(0.032)\end{array}$ & $\begin{array}{r}1.088 * * * \\
(0.137)\end{array}$ & $\begin{array}{r}1.247 * * * \\
(0.251)\end{array}$ & $\begin{array}{r}-0.032 * * * \\
(0.004)\end{array}$ & $\begin{array}{r}-0.027 * * * \\
(0.003)\end{array}$ & $\begin{array}{r}0.301 * * * \\
(0.086)\end{array}$ & $\begin{array}{r}0.031 \\
(0.074)\end{array}$ & $\begin{array}{r}0.823 * * * * \\
(0.092)\end{array}$ \\
\hline
\end{tabular}

Note: The table showed the outcomes of quantile coefficient. The value shown in the brackets is the value of standard errors. $* * *, * *$ and $*$ specify a level of significance at the $1 \%, 5 \%$, and $10 \%$ levels, correspondingly.

Source: Author Estimations 
The outcome established the fact that renewable energy increase should be encouraged by the Chinese's government. Indeed, emanations reduction to keep the temperature rise to not more than average of $2^{\circ} \mathrm{C}$ and avoiding the most unembellished influence of climate change can be achieved via the increased deployment of renewable energy efficiency in China. Since solar power can help reduce $\mathrm{CO}_{2}$ emanations mainly by being a clean and renewable source of energy. The result is equal to the researcher expectation, since, 2000, China's energy demand has grown over the years, but the adoption of all cost-effective measures could limit the growth. China alone represents $20 \%$ of global potential energy efficiency savings.

Furthermore, the null hypothesis across the quantiles of parameter constancy regarding $\beta \mathrm{FD}$ and $\beta \mathrm{URB}$ is rejected, which indicate that the parameter estimates of financial advancement and $\mathrm{CO}_{2}$ emanation are different across quantiles. For the long-term impact, the impact of financial advancement on $\mathrm{CO}_{2}$ emanation is 6.258 percent, which is statistically significant at 1 per cent, and this establishes the concave-shape connection between financial advancement and $\mathrm{CO}_{2}$ emanation in China. This segment of the study outcomes extends the finding of Zhang (2011). The results have shown that during the study period, $\mathrm{CO}_{2}$ emanation is significantly increased by the advancement in financial development in the long-run in China. This outcome is imperative from the perspective of environmental sustainability policy design. Also, the urbanization rate is a significant factor to be considered as our result shows that it has adverse impact on the environmental sustainability in China. As indicated in Table 3 , the urbanization rate explained 10.178 percent increases in $\mathrm{CO}_{2}$ emanation for every 1 percent increase in the urbanization rate in China. For the Chinese provinces, the similar finding was reported by Wang et al. (2016), which was further validated by the causal association reported by Ouyang and Lin (2017). The results demonstrate that the portfolio of existing urban development policies in China is proving to be unsustainable from ecological perspective.

In order to investigate the association between the determinants of $\mathrm{CO}_{2}$ emanations and $\mathrm{CO}_{2}$ emanation is presented in the Wald Test (Table-4). As indicated in the Wald test, the null hypothesis of parameter constancy with regards to the short-run effect of renewable energy, financial advancement, and urbanization on $\mathrm{CO}_{2}$ emanation is rejected across the quantiles in China. The study concludes that urbanization, financial advancement, and energy renewable exert an asymmetric contemporaneous and lagged influence on $\mathrm{CO}_{2}$ emanation in China as Wald test rejects the null hypothesis of parameter constancy across all quantiles for both lags. Additionally, the parameter constancy for the one-period lagged influence of $\mathrm{CO}_{2}$ emanations of their present values' the null hypothesis is rejected by the Wald test. It can be concluded that renewable energy, financial advancement, and urbanization determine $\mathrm{CO}_{2}$ emanation in the short term along all quantiles in China.

\begin{tabular}{|c|r|}
\hline \multicolumn{2}{|l|}{ Table-4: Results of the Wald Test } \\
\hline Variables & Wald-statistics \\
\hline $\boldsymbol{\rho}$ & $12.384^{* * *}$ \\
& $(0.000)$ \\
\hline $\boldsymbol{\beta}_{\mathrm{RENE}}$ & $9.324^{* * *}$ \\
& $(0.000)$ \\
\hline \multirow{2}{*}{$\boldsymbol{\beta}_{\mathrm{FD}}$} & $6.258^{* * *}$ \\
& $(0.009)$ \\
\hline $\boldsymbol{\beta}_{\mathrm{URB}}$ & $10.178^{* * *}$ \\
& $(0.000)$ \\
\hline \multirow{2}{*}{$\boldsymbol{\varphi}_{1}$} & $2.231^{* *}$ \\
& $(0.017)$ \\
\hline \multirow{2}{*}{$\mathbf{0}_{0}$} & $1.841^{* *}$ \\
& $(0.048)$ \\
\hline
\end{tabular}




\begin{tabular}{|c|c|}
\hline$\omega_{1}$ & $\begin{array}{r}0.971 \\
(0.489)\end{array}$ \\
\hline$\lambda_{0}$ & $\begin{array}{r}3.880^{* * * *} \\
(0.000)\end{array}$ \\
\hline$\lambda_{1}$ & $\begin{array}{r}0.135 \\
(0.999) \\
\end{array}$ \\
\hline$\theta_{0}$ & $\begin{array}{r}4.128^{* * *} \\
(0.000)\end{array}$ \\
\hline \multicolumn{2}{|c|}{ Cumulative short-term effect: } \\
\hline$\omega^{*}$ & $\begin{array}{r}11.362^{* * *} \\
(0.000)\end{array}$ \\
\hline$\lambda^{*}$ & $\begin{array}{r}14.112 * * * \\
(0.000)\end{array}$ \\
\hline
\end{tabular}

By comparing the results of the causality in the mean and quantile causality, Table- 5 presents the $p$ values of the quantile Granger causality test among Renewable Energy, Financial Advancement, Urbanization, and Carbon Dioxide Emanation. Results indicate evidence of strong causality running from Renewable Energy to $\mathrm{CO}_{2}$ emanations at most of the quantiles (0.05-0.95). The result indicates bidirectional causality running between renewable energy consumption and $\mathrm{CO}_{2}$ emanations. This segment of the outcome falls in line with the findings of Sinha et al. (2018) for the Next 11 economies. Similarly, a feedback effect is also obtained from Urbanization to $\mathrm{CO}_{2}$ emanations as both variables' granger causal each other. The result supports the findings of Wang et al. (2018), who revealed urbanization as a significant variable that causes $\mathrm{CO}_{2}$ emanation in the G-20 countries. Also, the test outcome in Table 5 showed evidence of bi-directional causality between financial advancement and $\mathrm{CO}_{2}$ emanations at ( 0.05 to 0.95 ). However, no evidence has been found for feedback between $\mathrm{CO}_{2}$ emanations and renewable energy at low quantile (0.05) and between financial advancement and $\mathrm{CO}_{2}$ emanations at middle quantile (0.40). Similarly, no feedback effect has been found between financial advancement and $\mathrm{CO}_{2}$ emanations, and urbanization and $\mathrm{CO}_{2}$ emanations, respectively, at 0.05 quantile. Finally, no causality has been found between $\mathrm{CO}_{2}$ emanations and urbanization at middle quantile (0.40). Additionally, $\mathrm{CO}_{2}$ emanation does not cause financial advancement at middle quantile (0.40).

\begin{tabular}{|c|c|c|c|c|c|c|}
\hline \multicolumn{7}{|c|}{ Table-5 Granger Causality in Quantile Test Results } \\
\hline Quantiles & $\begin{array}{c}\Delta \mathrm{RENE}_{\mathrm{t}} \\
\downarrow \\
\Delta \mathrm{CO} 2_{\mathrm{t}} \\
\end{array}$ & $\begin{array}{c}\Delta C O 2_{t} \\
\downarrow \\
\Delta \text { RENE }_{t}\end{array}$ & $\begin{array}{c}\Delta \mathrm{FD}_{\mathrm{t}} \\
\downarrow \\
\Delta \mathrm{CO2}{ }_{\mathrm{t}}\end{array}$ & $\begin{array}{c}\Delta \mathrm{CO} 2_{\mathrm{t}} \\
\downarrow \\
\Delta \mathrm{FD}_{\mathrm{t}}\end{array}$ & $\begin{array}{c}\Delta \mathrm{URB}_{\mathrm{t}} \\
\downarrow \\
\Delta \mathrm{CO2t}\end{array}$ & $\begin{array}{c}\Delta \mathrm{CO2} 2_{\mathrm{t}} \\
\downarrow \\
\Delta \mathrm{URB}_{\mathrm{t}}\end{array}$ \\
\hline$[0.05-0.95]$ & 0.000 & 0.000 & 0.000 & 0.000 & 0.000 & 0.000 \\
\hline 0.05 & 0.000 & 0.371 & 0.218 & 0.484 & 0.355 & 0.847 \\
\hline 0.10 & 0.000 & 0.000 & 0.000 & 0.000 & 0.000 & 0.000 \\
\hline 0.20 & 0.000 & 0.000 & 0.000 & 0.000 & 0.000 & 0.000 \\
\hline 0.30 & 0.000 & 0.000 & 0.000 & 0.000 & 0.000 & 0.000 \\
\hline 0.40 & 0.113 & 0.547 & 0.008 & 0.161 & 0.046 & 0.782 \\
\hline 0.50 & 0.000 & 0.000 & 0.000 & 0.000 & 0.000 & 0.000 \\
\hline 0.60 & 0.000 & 0.000 & 0.000 & 0.000 & 0.000 & 0.000 \\
\hline 0.70 & 0.000 & 0.000 & 0.000 & 0.000 & 0.000 & 0.000 \\
\hline 0.80 & 0.000 & 0.000 & 0.000 & 0.000 & 0.000 & 0.000 \\
\hline 0.90 & 0.000 & 0.000 & 0.000 & 0.000 & 0.000 & 0.000 \\
\hline 0.95 & 0.000 & 0.000 & 0.000 & 0.000 & 0.000 & 0.000 \\
\hline
\end{tabular}


The quantile causality approach was used by Troster et al. (2018) to examine the causal connection among renewable oil prices, energy utilization, and economic performance across quantiles in the USA. In another study of Cheng et al. (2019) investigates the effects of determinant variables (renewable energy supply and $\mathrm{CO}_{2}$ emanations per capita) on $\mathrm{CO}_{2}$ emanation and showed the strongest effect of renewable energy supply on $\mathrm{CO}_{2}$ emanations per capita at the 95th quantile and also, the feedback effect exists between financial advancement and $\mathrm{CO}_{2}$ emanations was reported by Zaidi et al. (2019) in a sample Asia Pacific Economic Cooperation (APEC) countries through the role of energy intensity. The study suggests the lowest negative variation of economic performance, and oil prices Granger cause the variations in renewable energy utilization.

\section{Conclusion and recommendation}

By far, the impact of renewable energy utilization, financial advancement, and urbanization on the $\mathrm{CO}_{2}$ emanations in China has been analyzed. Following a quantile modeling approach, study outcome have stated that on the one hand, renewable energy utilization helps in reducing the $\mathrm{CO}_{2}$ emanations, and on the other hand, financial advancement and urbanization augments the $\mathrm{CO}_{2}$ emanations. The causality analysis results divulge the existence of bidirectional causal associations between (a) renewable energy utilization and $\mathrm{CO}_{2}$ emanations, (b) financial advancement and $\mathrm{CO}_{2}$ emanations, and (c) urbanization and $\mathrm{CO}_{2}$ emanations.

Now, when these results are scrutinized from the perspective of policy designing, a number of insights emerge. China is one of the advanced economies in the world, and it is characterized by rapid industrialization. When industrialization sets in, the nation grows along with the organizations in the industrial ecosystem, and in order to sustain the growth, monetary mechanisms are designed accordingly. In this pursuit, the bank and other financial institutions in the nation strive to make the credits easily accessible to the organizations, so that they can utilize the fund for expansion and acquire of other projects. Needless to say, these growth opportunities lead to the formation of new urban centers around the nation, and emerging vocational opportunities attract the rural populace towards these urban centers. This movement goes beyond the urban centers, and shadow cities are formed around those urban centers, in the form of slums. This not only exerts pressure on the existing urban infrastructure, but also creates problems of energy efficiency, environmental degradation, and social issues. Mounting of these problems starts appearing to be barriers in the very way of implementing sustainable advancement goals in the nation. Therefore, the policy designs should incorporate these issues, and only then the growth will be inclusive and sustainable. In this context, we need to revisit the results of the causality tests. We have seen that one direction of causality runs from financial advancement and urbanization to $\mathrm{CO}_{2}$ emanations. The sustainability of any nation depends on the other side of the causality, as it reflects the negative externalities exerted by the ambient air pollution on the growth drivers, and that is the reason, sound policy design should incorporate the bi-directionality of associations among the model parameters (Zafar et al., 2019).

When the industrialization rises, urbanization also rises, and this creates a high demand for energy. If the nation tries to rely on traditional fossil fuel-based solutions, then the problem of ambient air pollution and other environmental degradation will aggravate. In order to tackle this situation, the policymakers should advise the implementation of renewable energy solutions. However, owing to the high cost of implementation, an overnight shift to cleaner production processes might not be possible, as it might have a negative consequence on the economic growth pattern. Therefore, policymakers should think of phase-wise solutions. During the first phase, the renewable energy solution should be provided to the industries against credit from banks and other financial institutions, and the poor households should be provided at a pro-rata rate from the local municipal bodies, with an interest rate holiday for 
three years. Now the interest income earned from the industries can be channelized for making the renewable energy solutions affordable to the poor households, in the form of subsidy. Now, in the second phase, the middle and high-income households will be provided with the solutions at a pro-rata rate, comparatively higher than the rate prescribed for the poor households. For them, the interest rate holiday can vary from one year to two years. One this phase-wise shift takes place, the loss of income from the households can be recovered from the interest income received from the industries. Therefore, the nation will not have to encounter a revenue deficit and consequential economic slowdown.

While saying this, it is also needed to remember that the policymakers need to implement the renewable energy solution not only to cater to the excess energy demand but also to promote cleaner production processes and encounter environmental degradation. This is where the other side of the causal association comes into the picture. It has been seen that the second direction of causality run from $\mathrm{CO}_{2}$ to financial advancement and urbanization. The rapid increase in the $\mathrm{CO}_{2}$ emanations will have a negative impact on the hygienic state of the labor force, and it will, in turn, hamper the economic growth pattern. Once the growth pattern is hit, the flow of money will also be consequently hit, i.e., the financial advancement cycle will be hit. In order to have control over this probable situation, the banks and financial institutions should introduce discretionary credit mechanism, which will be solely dependent on the "dirtiness" of the organization. By this mechanism, a dirtier organization will be charged with more rate of interest, compared to a cleaner organization. This will give the industries an incentive to reduce their waste, and the financial institutions should also form a legislative body for monitoring the generation of waste and pollution of the organizations. In this way, financial advancement will discourage not only the usage of fossil fuel-based solution but also the green energy initiatives, which might bring forth more green jobs within the nation. Thereby, the living standard of the urban populace will improve.

In order to facilitate this entire process, only the involvement of government or municipal bodies won't suffice, as it requires generating awareness among the citizens regarding the environmental and health concerns of fossil fuel utilization and the benefits of renewable energy solutions. Therefore, the policymakers should focus on encouraging people-publicprivate partnerships in increasing the level of environmental awareness among the citizens. This will help the policymakers to reach the grassroots level of implementation. In this course, the nation will be able to attain certain objectives of sustainable advancement goals (SDGs), namely (a) SDG 7: affordable and clean energy, (b) SDG 12: responsible utilization and production, (c) SDG 13: climate action, (d) SDG 11: sustainable cities and communities, and (e) SDG 8: decent work and economic growth. With the advent of renewable energy solutions and following a phase-wise implementation process, clean energy will be available to the citizens, and this will help in attaining the objective of SDG 7. Now, government enforcement of renewable energy implementation will entail the introduction of cleaner production processes across the industries, and the level of environmental awareness will help the citizens in identifying the ecologically sustainable utilization patterns. It will help the nation to achieve the objective of SDG 12. While both of these objectives are being fulfilled, the problem of environmental degradation will come down automatically, and thereby, accomplishing the objective of SDG 13. With renewable solutions and sufficient vocational opportunities in place, the cities will be sustaining on clean energy and well-knit communities, which might address the objective of SDG 11. Once all of these objectives are achieved, the nation can experience decent economic growth, thereby satisfying the objective of SDG 8. Lastly, in order to make the economic growth of a nation sustainable, the policymakers should focus on not only the mere physical capital behind the economic growth but also the human capital aspect, as human capital has the ability to transform the physical capital into economic benefits. 
Funding: No Funding has been received for this publication

Conflicts of interest/Competing interests: The authors declare no conflict of interest

Authors' contributions: Arshian Sharif ,Hamid Hussain ,Hammed Oluwaseyi Musibau and

Avik Sinha. All authors have equally contributed in idea generation, data gathering and preparation of this manuscript.

Data Availability Statement: All the data sets used in the current study are openly available on worldbank website and datastream.

Ethical Approval - Not Applicable

Consent to Participate - Not Applicable

Consent to Publish - Not Applicable

\section{References}

Ahmad, M., Khan, Z., Ur Rahman, Z., Khan, S., 2018. Does financial advancement asymmetrically affect $\mathrm{CO}_{2}$ emanations in China? An application of the nonlinear autoregressive distributed lag (NARDL) model. Carbon Management, 9(6), 631-644.

Al-Mulali, U., Ozturk, I., 2015. The effect of energy consumption, urbanization, trade openness, industrial output, and the political stability on the environmental degradation in the MENA (the Middle East and North African) region. Energy, 84, 382-389.

Al-Mulali, U., Sab, C.N.B.C., 2012. The impact of energy consumption and $\mathrm{CO}_{2}$ emanation on economic growth and financial advancement in the Sub Saharan African countries. Energy, 39(1), 180-186.

Al-Mulali, U., Sab, C.N.B.C., Fereidouni, H.G., 2012. Exploring the bi-directional long run relationship between urbanization, energy consumption, and carbon dioxide emission. Energy, 46(1), 156-167.

Apergis, N., Payne, J.E., 2010. Renewable energy consumption and economic growth: evidence from a panel of OECD countries. Energy Policy, 38(1), 656-660.

Apergis, N., Payne, J.E., 2015. Renewable energy, output, carbon dioxide emissions, and oil prices: evidence from South America. Energy Sources, Part B: Economics, Planning, and Policy, 10(3), 281-287.

Bilgili, F., Koçak, E., Bulut, Ü., 2016. The dynamic impact of renewable energy consumption on $\mathrm{CO}_{2}$ emissions: a revisited Environmental Kuznets Curve approach. Renewable and Sustainable Energy Reviews, 54, 838-845.

Boutabba, M.A., 2014. The impact of financial advancement, income, energy and trade on carbon emanations: Evidence from the Indian economy. Economic Modelling, 40, 3341.

Charfeddine, L., Khediri, K.B., 2016. Financial advancement and environmental quality in UAE: Cointegration with structural breaks. Renewable and Sustainable Energy Reviews, 55, 1322-1335.

Cho, J.S., Kim, T.H., Shin, Y., 2015. Quantile cointegration in the autoregressive distributedlag modeling framework. Journal of Econometrics, 188(1), 281-300.

Cole, M.A., Neumayer, E., 2004. Examining the impact of demographic factors on air pollution. Population and Environment, 26(1), 5-21.

Dechezleprêtre, A., Martin, R., Bassi, S., 2016. Climate change policy, innovation and growth. Grantham Research Institute \& Global Green Growth Institute, London.

Derbali, A., 2017. Economic growth, financial advancement, trade openness, and $\mathrm{CO}_{2}$ emanations in European countries. Financial Advancement, Trade Openness, and $\mathrm{CO}_{2}$ Emanations in European Countries (November 28, 2017). Retrieved from https://papers.ssrn.com/sol3/papers.cfm?abstract_id=3078975 
Dogan, E., Seker, F., 2016a. The influence of real output, renewable and non-renewable energy, trade and financial development on carbon emissions in the top renewable energy countries. Renewable and Sustainable Energy Reviews, 60, 1074-1085.

Dogan, E., Seker, F., 2016b. Determinants of $\mathrm{CO}_{2}$ emissions in the European Union: The role of renewable and non-renewable energy. Renewable Energy, 94, 429-439.

Frankel, J.A., 2009. Environmental effects of international trade. HKS Faculty Research Working Paper Series RWP09-006, John F. Kennedy School of Government, Harvard University.

Galvao Jr, A.F., 2009. Unit root quantile autoregression testing using covariates. Journal of Econometrics, 152(2), 165-178.

Gokmenoglu, K., Ozatac, N., \& Eren, B. M. (2015). Association between industrial production, financial advancement and carbon emanations: The case of Turkey. Procedia Economics and Finance, 25, 463-470.

Hao, Y., Zhang, Z. Y., Liao, H., Wei, Y. M., \& Wang, S. (2016). Is CO 2 emanation a side effect of financial advancement? An empirical analysis for China. Environmental Science and Pollution Research, 23(20), 21041-21057.

Haseeb, A., Xia, E., Baloch, M. A., \& Abbas, K. (2018). Financial advancement, globalization, and $\mathrm{CO} 2$ emanation in the presence of EKC: evidence from BRICS countries. Environmental Science and Pollution Research, 25(31), 31283-31296.

Hsu, S., 2016. China's Urbanization Plans Need To Move Faster In 2017. Forbes. Available at: https://www.forbes.com/sites/sarahsu/2016/12/28/chinas-urbanization-plans-need-tomove-faster-in-2017/

Jalil, A., \& Feridun, M. (2011). The impact of growth, energy and financial advancement on the environment in China: a cointegration analysis. Energy Economics, 33(2), 284-291.

Jalil, A., \& Feridun, M. (2011). The impact of growth, energy and financial development on the environment in China: a cointegration analysis. Energy Economics, 33(2), 284-291.

Jalil, A., \& Feridun, M. (2011). The long-run association between income inequality and financial advancement in China. Journal of the Asia Pacific Economy, 16(2), 202-214.

Jalil, A., Feridun, M., \& Ma, Y. (2010). Finance-growth nexus in China revisited: New evidence from principal components and ARDL bounds tests. International Review of Economics \& Finance, 19(2), 189-195.

Jennings, R., 2018. Despite China's Fast-Growing Wealth, Millions Still Remain Poor. Forbes. Available at: https:/www.forbes.com/sites/ralphjennings/2018/02/04/why-tens-ofmillions-remain-poor-in-china-despite-fast-growing-wealth/

Khoshnevis Yazdi, S., \& Shakouri, B. (2018). The effect of renewable energy and urbanization on CO2 emanations: A panel data. Energy Sources, Part B: Economics, Planning, and Policy, 13(2), 121-127.

Kirby, P. (2016). The Celtic tiger in distress: Growth with inequality in Ireland. Springer.

Koenker, R., \& Xiao, Z. (2004). Unit root quantile autoregression inference. Journal of the American Statistical Association, 99(467), 775-787.

Liddle, B. (2014). Impact of population, age structure, and urbanization on carbon emissions/energy consumption: evidence from macro-level, cross-country analyses. Population and Environment, 35(3), 286-304.

Ma, C., \& Stern, D. I. (2008). Biomass and China's carbon emanations: A missing piece of carbon decomposition. Energy Policy, 36(7), 2517-2526.

Maiti, S., \& Agrawal, P. K. (2005). Environmental degradation in the context of growing urbanization: a focus on the metropolitan cities of India. Journal of Human Ecology, 17(4), 277-287.

Marrero, G. A. (2009). Greenhouse gases emanations, growth and the energy mix in Europe: a dynamic panel data approach. Documento de Trabajo, 2009, 16. 
Martínez-Zarzoso, I., Bengochea-Morancho, A., \& Morales-Lage, R. (2007). The impact of population on $\mathrm{CO} 2$ emanations: evidence from European countries. Environmental and Resource Economics, 38(4), 497-512.

Meadows, D.L., 1974. Limits to Growth a Finite World. Cambrige University Press.

Menyah, K., \& Wolde-Rufael, Y. (2010). CO2 emanations, nuclear energy, renewable energy and economic growth in the US. Energy Policy, 38(6), 2911-2915.

Mielnik, O., \& Goldemberg, J. (2002). Foreign direct investment and decoupling between energy and gross domestic product in developing countries. Energy policy, 30(2), 8789.

Mishra, S., Sharif, A., Khuntia, S., Meo, S. A., \& Khan, S. A. R. (2019). Does oil prices impede Islamic stock indices? Fresh insights from wavelet-based quantile-on-quantile approach. Resources Policy, 62, 292-304.

Nejat, P., Jomehzadeh, F., Taheri, M. M., Gohari, M., \& Majid, M. Z. A. (2015). A global review of energy consumption, $\mathrm{CO} 2$ emanations and policy in the residential sector (with an overview of the top ten $\mathrm{CO} 2$ emitting countries). Renewable and sustainable energy reviews, 43, 843-862.

Ozturk, I., \& Acaravci, A. (2013). The long-run and causal analysis of energy, growth, openness and financial advancement on carbon emanations in Turkey. Energy Economics, 36, 262-267.

Ouyang, X., \& Lin, B. (2017). Carbon dioxide (CO2) emissions during urbanization: A comparative study between China and Japan. Journal of Cleaner Production, 143, 356368.

Parikh, J., \& Shukla, V. (1995). Urbanization, energy use and greenhouse effects in economic advancement: Results from a cross-national study of developing countries. Global environmental change, 5(2), 87-103.

Payne, J. E. (2011). On biomass energy consumption and real output in the US. Energy Sources, Part B: Economics, Planning, and Policy, 6(1), 47-52.

Pineiro Chousa, J., Tamazian, A., \& Vadlamannati, K. C. (2017). Does Higher Economic and Financial Advancement Lead to Environmental Degradation: Evidence from BRIC Countries.

Pineiro-Chousa, J., Vizcaíno-González, M., López-Cabarcos, M., \& Romero-Castro, N. (2017). Managing reputational risk through environmental management and reporting: An options theory approach. Sustainability, 9(3), 376.

Poumanyvong, P., \& Kaneko, S. (2010). Does urbanization lead to less energy use and lower $\mathrm{CO} 2$ emanations? A cross-country analysis. Ecological Economics, 70(2), 434-444.

Qi, Y., \& Wu, T. (2013). The politics of climate change in China. Wiley Interdisciplinary Reviews: Climate Change, 4(4), 301-313.

Sadorsky, P. (2009). Renewable energy consumption, CO2 emanations and oil prices in the G7 countries. Energy Economics, 31(3), 456-462.

Sadorsky, P. (2010). The impact of financial advancement on energy consumption in emerging economies. Energy policy, 38(5), 2528-2535.

Saidi, K., \& Mbarek, M. B. (2017). The impact of income, trade, urbanization, and financial development on CO 2 emissions in 19 emerging economies. Environmental Science and Pollution Research, 24(14), 12748-12757.

Salahuddin, M., Alam, K., Ozturk, I., \& Sohag, K. (2018). The effects of electricity consumption, economic growth, financial development and foreign direct investment on CO2 emissions in Kuwait. Renewable and Sustainable Energy Reviews, 81, 20022010.

Salim, R. A., \& Rafiq, S. (2012). Why do some emerging economies proactively accelerate the adoption of renewable energy?. Energy Economics, 34(4), 1051-1057. 
Shafiei, S., \& Salim, R. A. (2014). Non-renewable and renewable energy consumption and $\mathrm{CO} 2$ emanations in OECD countries: A comparative analysis. Energy Policy, 66, 547556.

Shahbaz, M., \& Lean, H. H. (2012). Does financial advancement increase energy consumption? The role of industrialization and urbanization in Tunisia. Energy policy, 40, 473-479.

Shahbaz, M., Haouas, I., \& Van Hoang, T. H. (2019). Economic growth and environmental degradation in Vietnam: Is the environmental Kuznets curve a complete picture?. Emerging Markets Review, 38, 197-218.

Shahbaz, M., Hye, Q. M. A., Tiwari, A. K., \& Leitão, N. C. (2013). Economic growth, energy consumption, financial development, international trade and $\mathrm{CO} 2$ emissions in Indonesia. Renewable and Sustainable Energy Reviews, 25, 109-121.

Shahbaz, M., Khan, S., \& Tahir, M. I. (2013). The dynamic links between energy consumption, economic growth, financial advancement and trade in China: fresh evidence from multivariate framework analysis. Energy Economics, 40, 8-21.

Shahbaz, M., \& Sinha, A. (2019). Environmental Kuznets curve for CO2 emissions: a literature survey. Journal of Economic Studies, 46(1), 106-168.

Shahbaz, M., Zakaria, M., Shahzad, S. J. H., \& Mahalik, M. K. (2018). The energy consumption and economic growth nexus in top ten energy-consuming countries: Fresh evidence from using the quantile-on-quantile approach. Energy Economics, 71, 282301.

Shahzad, S. J. H., Kumar, R. R., Zakaria, M., \& Hurr, M. (2017). Carbon emission, energy consumption, trade openness and financial development in Pakistan: A revisit. Renewable and Sustainable Energy Reviews, 70, 185-192.

Sharif, A., Afshan, S., \& Qureshi, M. A. (2019). Idolization and ramification between globalization and ecological footprints: evidence from quantile-on-quantile approach. Environmental Science and Pollution Research, 26(11), 11191-11211.

Sharif, A., Mishra, S., Sinha, A., Jiao, Z., Shahbaz, M., \& Afshan, S. (2020). The renewable energy consumption-environmental degradation nexus in Top-10 polluted countries: Fresh insights from quantile-on-quantile regression approach. Renewable Energy, 150, 670-690.

Sharif, A., Raza, S. A., Ozturk, I., \& Afshan, S. (2019). The dynamic relationship of renewable and nonrenewable energy consumption with carbon emission: A global study with the application of heterogeneous panel estimations. Renewable Energy, 133, 685-691.

Sharif, A., Shahbaz, M., \& Hille, E. (2019). The Transportation-growth nexus in USA: Fresh insights from pre-post global crisis period. Transportation Research Part A: Policy and Practice, 121, 108-121.

Sharma, S. S. (2011). Determinants of carbon dioxide emanations: empirical evidence from 69 countries. Applied Energy, 88(1), 376-382.

Shin, Y., Yu, B., \& Greenwood-Nimmo, M. (2011). Modelling Asymmetric Cointegration and Dynamic Multiplier in a Nonlinear ARDL Framework, Mimeo.

Sinha, A., Shahbaz, M., \& Balsalobre, D. (2017). Exploring the relationship between energy usage segregation and environmental degradation in $\mathrm{N}-11$ countries. Journal of Cleaner Production, 168, 1217-1229.

Sinha, A., Shahbaz, M., \& Sengupta, T. (2018). Renewable energy policies and contradictions in causality: a case of Next 11 countries. Journal of Cleaner Production, 197, 73-84.

Sinha, A., Gupta, M., Shahbaz, M., \& Sengupta, T. (2019). Impact of corruption in public sector on environmental quality: Implications for sustainability in BRICS and next 11 countries. Journal of Cleaner Production, 232, 1379-1393. 
Sinha, A., Sengupta, T., \& Alvarado, R. (2020). Interplay between technological innovation and environmental quality: formulating the SDG policies for next 11 economies. Journal of Cleaner Production, 242, 118549.

Stern, D. I., \& Common, M. S. (2001). Is there an environmental Kuznets curve for sulfur?. Journal of Environmental Economics and Management, 41(2), 162-178.

Tamazian, A., \& Rao, B. B. (2010). Do economic, financial and institutional developments matter for environmental degradation? Evidence from transitional economies. Energy Economics, 32(1), 137-145.

Tamazian, A., Chousa, J. P., \& Vadlamannati, K. C. (2009). Does higher economic and financial advancement lead to environmental degradation: evidence from BRIC countries. Energy policy, 37(1), 246-253.

Tang, C. F., \& Tan, B. W. (2014). The linkages among energy consumption, economic growth, relative price, foreign direct investment, and financial development in Malaysia. Quality \& Quantity, 48(2), 781-797.

Uchiyama, K. (2016). Environmental Kuznets curve hypothesis. Environmental Kuznets curve hypothesis and carbon dioxide emanations (pp. 11-29). Springer, Tokyo.

UNDP, 2012. Large slums, rising emissions pose double threat to Asia-Pacific cities. Available at:

https://www.undp.org/content/undp/en/home/presscenter/pressreleases/2012/07/03/lar ge-slums-and-rising-emissions-pose-double-threat-to-green-prospects-for-asiapacific-cities.html

Wang, Q., Zeng, Y. E., \& Wu, B. W. (2016). Exploring the relationship between urbanization, energy consumption, and $\mathrm{CO} 2$ emissions in different provinces of China. Renewable and sustainable energy reviews, 54, 1563-1579.

Wang, Y., Chen, L., \& Kubota, J. (2016). The relationship between urbanization, energy use and carbon emissions: evidence from a panel of Association of Southeast Asian Nations (ASEAN) countries. Journal of Cleaner Production, 112, 1368-1374.

World Bank, 2018. World Development Indicators. Available at: https://data.worldbank.org/indicator/

Xing, T., Jiang, Q., Ma, X. (2017), To facilitate or curb? The role of financial advancement in China's carbon emanations reduction process: A novel approach. International Journal of Environmental Research and Public Health, 14(10), 1-39

Yuxiang, K., \& Chen, Z. (2011). Financial advancement and environmental performance: evidence from China. Environment and Advancement Economics, 16(1), 93-111.

Zafar, M. W., Shahbaz, M., Hou, F., \& Sinha, A. (2019). From nonrenewable to renewable energy and its impact on economic growth: the role of research \& development expenditures in Asia-Pacific Economic Cooperation countries. Journal of Cleaner Production, 212, 1166-1178.

Zaidi, S. A. H., Zafar, M. W., Shahbaz, M., \& Hou, F. (2019). Dynamic linkages between globalization, financial advancement and carbon emanations: Evidence from Asia Pacific Economic Cooperation countries. Journal of Cleaner Production, 228, 533-543.

Zhang, Y. J. (2011). The impact of financial advancement on carbon emanations: An empirical analysis in China. Energy Policy, 39(4), 2197-2203.

Zhang, Y.J., 2011. The impact of financial development on carbon emissions: An empirical analysis in China. Energy Policy, 39(4), 2197-2203.

Zhang, Y.J., Liu, Z., Zhang, H., \& Tan, T. D. (2014). The impact of economic growth, industrial structure and urbanization on carbon emission intensity in China. Natural hazards, 73(2), 579-595. 
Ziaei, S. M. (2015). Effects of financial advancement indicators on energy consumption and $\mathrm{CO} 2$ emanation of European, East Asian and Oceania countries. Renewable and Sustainable Energy Reviews, 42, 752-759. 